\title{
FAKTOR-FAKTOR YANG MEMPENGARUHI STRES KELUARGA DALAM MERAWAT PENDERITA KANKER SERVIKS
}

\author{
Sri Dewi Zalmi ${ }^{1}$, Yulia Irvani Dewi, Jumaini ${ }^{3}$ \\ ${ }^{1,2,3}$ Fakultas Keperawatan Universitas Riau \\ Fakultas Keperawatan Universitas Riau Jalan Pattimura No 9 \\ Gedung G Pekanbaru Riau Kode Pos 28131 Indonesia \\ Email: dewizalmi19@gmail.com
}

\begin{abstract}
Abstrak
Kanker serviks merupakan pembunuh utama pada wanita setelah kanker payudara. Kanker serviks berdampak terhadap kehidupan penderita dan keluarganya, salah satu dampak yang dirasakan keluarga adalah stres selama merawat anggota keluarga yang mengalami kanker serviks. Penelitian ini bertujuan untuk mengetahui faktor-faktor yang mempengaruhi stres keluarga dalam merawat penderita kanker serviks. Metode yang digunakan dalam penelitian ini adalah deskriptif korelasi dengan pendekatan crossectional. Sampel penelitian berjumlah 53 responden yang diambil berdasarkan teknik accidental sampling di RSUD Arifin Achmad Provinsi Riau. Alat ukur yang digunakan dalam penelitian ini adalah kuesioner yang telah dilakukan uji validitas dan reliabilitas. Analisis yang digunakan adalah analisis univariat menggunakan distribusi frekuensi dan bivariat menggunakan uji Chi-square. Hasil analisis bivariat menunjukkan tidak terdapat hubungan antara pengetahuan keluarga dalam merawat penderita kanker serviks $p$ value $(0,491)>\alpha$ $(0,05)$ dan terdapat hubungan antara persepsi kelarga terhadap penyakit $p$ value $(0,000)<\alpha(0,05)$, biaya perawatan $p$ value $(0,003)<\alpha(0,05)$, proses perawatan $p$ value $(0,004)<\alpha(0,05)$ terhadap stres keluarga dalam merawat penderita kanker serviks. Direkomendasikan untuk tenaga kesehatan agar ikut serta memperhatikan kebutuhan psikososial keluarga, memberi dukungan kepada keluarga serta melakukan komunikasi terapeutik dengan keluarga pasien agar dapat mengurangi stres keluarga dalam merawat penderita kanekr serviks.
\end{abstract}

Kata kunci: Kanker serviks, Keluarga, Merawat, Stres

\begin{abstract}
Cervical cancer is a killer in women after breast cancer. Cervical cancer affects the lives of sufferers and their families, one of the effects that families feel is stress while caring for family members who have cervical cancer. This study aims to determine the factors that influence family stress in treating patients with cervical cancer. The method used in this research is descriptive correlation with crossectional approach. The research sample was 53 respondents taken based on accidental sampling technique in the General Hospital Riau Province. The measuring instrument used in this study is a questionnaire that has been tested for validity and reliability. The analysis used was univariate analysis using frequency distribution and bivariate using Chisquare test. The results of the bivariate analysis showed that there was no relationship between family
\end{abstract}


Sri Dewi Zalmi ${ }^{1}$, Yulia Irvani Dewi ${ }^{2}$, Jumaini ${ }^{3}$, Faktor-faktor yang Mempengaruhi Stress Keluarga dalam Merawat Penderita Kanker Serviks

knowledge in treating cervical cancer patients $p$ value (0.491)> $\alpha(0.05)$ and there was a relationship between clan perceptions of disease $p$ value $(0.000)<\alpha(0.05)$, maintenance costs $p$ value $(0.003)<\alpha(0.05)$, the treatment process $p$ value $(0.004)<\alpha(0.05)$ for family stress in treating cervical cancer patients. It is recommended for health workers to participate in paying attention to family psychosocial needs, provide support to the family and conduct therapeutic communication with the patient's family in order to reduce family stress in treating cervical cancer patients

Keywords: Cervical cancer, Care, Family, Stress

\section{PENDAHULUAN}

Kanker serviks adalah pertumbuhan selsel abnormal yang mengalami dysplasia pada bagian mulut rahim atau serviks (Supriyanto, 2015). Kanker ini terjadi pada daerah mulut rahim yaitu daerah pada organ reproduksi wanita yang merupakan pintu masuk ke arah rahim yang terletak antara rahim dan vagina (Smart, 2010). Berdasarkan data Globocan International Agency for Research on Cancer (IARC), tahun 2018, terdapat 569.847 kasus baru kanker servik serta diperkirakan ada 311.365 kematian akibat kanker serviks di seluruh dunia. Di Indonesia, prevalensi kejadian kanker serviks juga cukup tinggi, yaitu pada tahun 2013 tercatat sebanyak 98.692 kejadian, sedangkan di provinsi Riau terdapat 894 kejadian (Pusdatin, 2015). Prevalensi kanker serviks di RSUD Arifin
Achmad juga mengalami peningkatan, dimana tercatat selama tahun 2017 terdapat 424 pasien sedangkan pada tahun 2018 tercatat sebanyak 569 pasien dan 294 pasien dari Januari sampai Juni.

Kanker serviks tidak hanya mempengaruhi kehidupan penderita, tetapi juga mempengaruhi keluarga penderita. Menurut Kharisma (2014) ketika ada salah satu anggota keluarga yang didiagnosa dengan kanker, maka keluarga akan merasa sedih, khawatir, takut, lelah, kasihan dan susah saat mendampingi anggota keluarganya menjalani perawatan. Maka ini akan menyebabkan gangguan baik secara fisik ataupun psikologis keluarga yaitu berupa stres. Saat keluarga mengalami distres maka ini dapat berdampak terhadap kesehatan dan menyebabkan sakit. Dalam keadaan sakit keluarga tidak mampu 
malaksanakan fungsi-fungsi yang seharusnya dilaksanakan sehingga akan mengakibatkan dukungan keluarga berkurang dan menyebabkan anggota keluarga yang sedang sakit penyembuhannya akan semakin lama (Sentan 2016, dalam Husna 2018).

Berdasarkan fenomena diatas peneliti tertarik untuk melakukan penelitian tentang "Faktor-faktor yang mempengaruhi stres keluarga dalam merawat penderita kanker serviks". Tujuan dari penelitian ini adalah untuk mengetahui faktor-faktor apa saja yang dapat mempengaruhi stres keluarga dalam merawat penderita kanker serviks.

\section{METODE PENELITIAN}

Penelitian dilakukan RSUD Arifin Achmad Provinsi Riau yang dimulai bulan Februari sampai Juli 2019. Penelitian ini menggunakan desain penelitian deskriptif Tabel 1 korelasi. Pengambilan sampel menggunakan teknik accidental sampling dengan 53 responden. Kriteria inklusi untuk sampel dalam penelitian ini adalah keluarga inti (suami atau anak) yang menemani pasien kanker serviks di ruang rawat Tulip dan Seruni Obgyn serta bersedia menjadi responden.

Alat pengumpul data dalam penelitian ini adalah kuesioner untuk mengetahui karakteristik responden, kuesioner tingkat stres DASS dan kuesioner faktor-faktor yang mempengaruhi stres keluarga dalam merawat penderita kanker serviks. Analisis data yang digunakan yaitu analisis univariat dan analisis biavariat. Penelitian Ini telah dilakukan uji etik pada komite etik Fakultas Keperawatan Universitas Riau, tanggal 12 April 2019 nomor: 077/UN.19.5.1.1.8/UEPPK/2019.

\section{HASIL PENELITIAN}

\section{Analisis Univariat}

Distribusi frekuensi responden berdasarkan usia, jenis kelamin, pekerjaan dan hubungan dengan pasien

\begin{tabular}{clcc}
\hline No & Karakteristik Responden & Jumlah & Persentase (\%) \\
\hline 1. & Umur & 24 & 45,3 \\
& - Dewasa awal (18-40 tahun) & 21 & 39,6 \\
& - Dewasa menengah (41-60 tahun) & 8 & 15,1 \\
\hline & - Lansia (>60 tahun) & & 56,6 \\
\hline 2 & Jenis Kelamin & 30 & 43,4 \\
& - Laki-laki & 23 & \\
& - Perempuan & & 18,9
\end{tabular}


Sri Dewi Zalmi ${ }^{1}$, Yulia Irvani Dewi ${ }^{2}$, Jumaini ${ }^{3}$, Faktor-faktor yang Mempengaruhi Stress Keluarga dalam Merawat Penderita Kanker Serviks

\begin{tabular}{llcc}
\hline No & Karakteristik Responden & Jumlah & Persentase (\%) \\
\hline \multirow{2}{*}{$\cdot$ - Wiraswasta } & - PNS & 10 & 18,9 \\
& - Lain-lain & 3 & 5,7 \\
\hline 4 & Hubungan dengan pasien & 30 & 56,6 \\
& - Suami & & \\
& - Anak & 22 & 41,5 \\
\end{tabular}

Tabel 1 menunjukkan mayoritas keluarga lain-lain (petani, buruh, tidak bekerja, ibu berada pada rentang umur dewasa awal rumah tangga dan sebagainya) yaitu sebanyak sebanyak 24 orang $(45,3 \%)$. Dilihat dari jenis 30 orang $(56,6 \%)$. Sebagian besar responden kelamin diketahui sebagian besar responden adalah anak dari penderita kanker serviks berjenis kelamin laki-laki sebanyak 30 orang sebanyak $31 \quad$ orang $\quad(58,5 \%)$. (56,6\%). Mayoritas keluarga bekerja sebagai

Tabel 2

Distribusi responden berdasarkan tingkat stres, pengetahuan keluarga dalam merawat penderita kanker serviks, persepsi keluarga terhadap penyakit kanker serviks, biaya perawatan kanker serviks dan proses perawatan kanker serviks

\begin{tabular}{|c|c|c|c|}
\hline No & Karakteristik Responden & Jumlah & Persentase (\%) \\
\hline \multirow[t]{3}{*}{1} & Tingkat stres & & \\
\hline & - Sedang & 27 & 50,9 \\
\hline & - Ringan & 26 & 49,1 \\
\hline \multirow[t]{3}{*}{2} & Pengetahuan keluarga dalam merawat & & \\
\hline & - Baik & 51 & 96,2 \\
\hline & - Kurang Baik & 2 & 3,8 \\
\hline \multirow[t]{3}{*}{3} & Persepsi keluarga terhadap penyakit & & \\
\hline & - Positif & 27 & 50,9 \\
\hline & - Negatif & 26 & 49,1 \\
\hline \multirow[t]{3}{*}{4} & Biaya perawatan & & \\
\hline & - Terbebani & 28 & 52,8 \\
\hline & _ $\quad$ Tidak terbebani & 25 & 47,2 \\
\hline \multirow[t]{3}{*}{5} & Proses perawatan & & \\
\hline & - Terbebani & 28 & 52,8 \\
\hline & _ Tidak terbebani & 25 & 47,2 \\
\hline
\end{tabular}

Tabel 2 menunjukkan sebagian besar keluarga mengalami tingkat stres sedang dalam merawat penderita kanker serviks yaitu sebanyak 27 orang (50,9\%). Pengetahuan keluarga dalam merawat penderita kanker serviks mayoritas memiliki pengetahuan yang baik yaitu sebanyak 51 orang $(96,2 \%)$.
Mayorias keluarga memiliki persepsi positif terhadap penyakit kanker serviks sebanyak 27 orang $(50,9 \%)$. Biaya perawatan kanker serviks didapatkan bahwa sebagian besar keluarga terbebani yaitu sebanyak 28 orang $(52,8 \%)$. Berdasarakan proses perawatan kanker serviks didapatkan sebagian besar 
keluarga terbebani yaitu sebanyak 28 orang

$(52,8 \%)$.

\section{Analisis Bivariat}

Tabel 3

Hubungan pengetahuan keluarga dalam merawat penderita kanker serviks dengan tingkat stres keluarga dalam merawat penderita kanker serviks

\begin{tabular}{|c|c|c|c|c|c|c|c|}
\hline \multirow{3}{*}{ No } & \multirow{3}{*}{$\begin{array}{l}\text { Pengetahuan keluarga } \\
\text { dalam merawat }\end{array}$} & \multicolumn{4}{|c|}{ Tingkat stres keluarga } & \multirow{3}{*}{ Jumlah } & \multirow{3}{*}{$p$-value } \\
\hline & & \multicolumn{2}{|c|}{ Sedang } & \multicolumn{2}{|c|}{ Ringan } & & \\
\hline & & $\mathrm{n}$ & $\%$ & $\mathrm{n}$ & $\%$ & & \\
\hline 1 & Baik & 25 & 49,0 & 26 & 51,0 & 51 & \\
\hline \multirow[t]{2}{*}{2} & Kurang baik & 2 & 100 & 0 & 0,00 & 2 & 0,491 \\
\hline & Total & 27 & 50,9 & 26 & 49,1 & 53 & \\
\hline
\end{tabular}

Tabel 3 menunjukkan bahwa responden statistik Fisher diketahui $p$-value=0,491, yang yang memiliki pengetahuan baik mengalami berarti Ho gagal ditolak. Disimpulkan tidak tingkat stres sedang sebanyak $49 \%$ dan terdapat hubungan antara pengetahuan sebanyak 51\% responden merasakan tingkat keluarga dalam merawat penderita kanker stres yang ringan. Sedangkan responden yang serviks dengan tingkat stres keluarga dalam memiliki pengetahuan kurang baik mengalami merawat penderita kanker serviks. tingkat stres sedang sebanyak $100 \%$. Hasil uji

Tabel 4

Hubungan persepsi keluarga terhadap penyakit kanker serviks dengan tingkat stres keluarga dalam merawat penderita kanker serviks

\begin{tabular}{|c|c|c|c|c|c|c|c|}
\hline \multirow{3}{*}{ No } & \multirow{3}{*}{ Persepsi keluarga } & \multicolumn{4}{|c|}{ Tingkat stres keluarga } & \multirow{3}{*}{ Jumlah } & \multirow{3}{*}{$p$-value } \\
\hline & & \multicolumn{2}{|c|}{ Sedang } & \multicolumn{2}{|c|}{ Ringan } & & \\
\hline & & $\mathrm{n}$ & $\%$ & $\mathrm{n}$ & $\%$ & & \\
\hline 1 & Positif & 5 & 18,5 & 22 & 81,5 & 27 & \multirow{3}{*}{0,000} \\
\hline 2 & Negatif & 22 & 84,6 & 4 & 15,4 & 26 & \\
\hline & Total & 27 & 50,9 & 26 & 49,1 & 53 & \\
\hline
\end{tabular}

Tabel 4 menunjukkan bahwa responden yang memiliki persepsi positif mengalami tingkat stres sedang sebanyak $18,5 \%$ dan sebanyak $81,5 \%$ responden mengalami tingkat stres yang ringan. Sementara itu responden yang memiliki persepsi negatif mengalami tingkat stres sedang sebanyak $84,6 \%$ dan sebanyak $15,4 \%$ responden merasakan tingkat stres yang ringan. Hasil uji statistik chi-square diketahui $p$-value $=0,000$, yang berarti Ho ditolak. Disimpulkan terdapat hubungan antara persepsi keluarga terhadap penyakit kanker serviks dengan tingkat stres keluarga dalam merawat penderita kanker serviks. 
Sri Dewi Zalmi ${ }^{1}$, Yulia Irvani Dewi ${ }^{2}$, Jumaini ${ }^{3}$, Faktor-faktor yang Mempengaruhi Stress Keluarga dalam Merawat Penderita Kanker Serviks

Tabel 5

Hubungan biaya perawatan kanker serviks dengan tingkat stres keluarga dalam merawat penderita kanker serviks

\begin{tabular}{|c|c|c|c|c|c|c|c|}
\hline \multirow{3}{*}{ No } & \multirow{3}{*}{ Biaya perawatan } & \multicolumn{4}{|c|}{ Tingkat stres keluarga } & \multirow{3}{*}{ Jumlah } & \multirow{3}{*}{ p-value } \\
\hline & & \multicolumn{2}{|c|}{ Sedang } & \multicolumn{2}{|c|}{ Ringan } & & \\
\hline & & $\mathrm{n}$ & $\%$ & $\mathrm{n}$ & $\%$ & & \\
\hline 1 & Terbebani & 23 & 67,6 & 11 & 32,4 & 27 & \\
\hline 2 & Tidak terbebani & 4 & 21,1 & 15 & 78,9 & 26 & 0,003 \\
\hline & Total & 27 & 50,9 & 26 & 49,1 & 53 & \\
\hline
\end{tabular}

Tabel 5 menunjukkan bahwa responden responden merasakan tingkat stres yang yang merasa terbebani dengan biaya ringan. Hasil uji statistik chi-square diketahui perawatan mengalami stres sedang sebanyak $p$-value $=0,003$ yang berarti Ho ditolak. $67,6 \%$ dan sebanyak $32,4 \%$ responden Disimpulkan terdapat hubungan antara biaya merasakan tingkat stres yang ringan. perawatan kanker serviks dengan tingkat stres Responden yang tidak terbebani dengan biaya keluarga dalam merawat penderita kanker perawatan dengan tingkat stres sedang serviks.

sebanyak $21,1 \%$ dan sebanyak $78,9 \%$

Tabel 6

Hubungan poses perawatan kanker serviks dengan tingkat stres keluarga dalam merawat penderita kanker serviks

\begin{tabular}{|c|c|c|c|c|c|c|c|}
\hline \multirow[t]{3}{*}{ No } & \multirow{3}{*}{ Proses perawatan } & \multicolumn{4}{|c|}{ Tingkat stres keluarga } & \multirow{3}{*}{ Jumlah } & \multirow{3}{*}{ p-value } \\
\hline & & \multicolumn{2}{|c|}{ Sedang } & \multicolumn{2}{|c|}{ Ringan } & & \\
\hline & & $\mathrm{n}$ & $\%$ & $\mathrm{n}$ & $\%$ & & \\
\hline 1 & Terbebani & 20 & 71,4 & 8 & 28,6 & 27 & \\
\hline \multirow[t]{2}{*}{2} & Tidak Terbebani & 7 & 28,0 & 18 & 72,0 & 26 & 0,004 \\
\hline & Total & 27 & 50,9 & 26 & 49,1 & 53 & \\
\hline
\end{tabular}

Tabel 6 menunjuukkan bahwa responden sebanyak $72 \%$ responden merasakan tingkat yang merasa terbebani dengan proses stres yang ringan. Hasil uji statistik chi-square perawatan mengalami tingkat stres sedang diketahui $p$-value $=0,004$, yang berarti Ho sebanyak $71,4 \%$ dan sebanyak $28,6 \%$ ditolak. Disimpulkan terdapat hubungan antara responden merasakan tingkat stres yang proses perawatan kanker serviks dengan ringan. Responden yang merasa tidak tingkat stres keluarga dalam merawat penderita terbebani dengan proses perawatan mengalami kanker serviks. tingkat stres sedang sebanyak $28 \%$ dan 


\section{PEMBAHASAN}

\section{Analisis Univariat}

Karakteristik responden berdasarkan umur didapatkan mayoritas berada pada rentang dewasa awal (18-40 tahun) yaitu sebanyak 24 orang (45,3\%). Menurut Hurlock (1996) dalam Retno (2019) salah satu ciri dari masa dewasa awal ialah sebagai masa pengaturan dimana pada masa inilah dimulai untuk menerima tanggung jawab sebagai orang dewasa.

Karakteristik responden berdasarkan jenis kelamin diketahui responden terbanyak berjenis kelamin laki laki yaitu berjumlah 30 orang responden $(56,6 \%)$. Menurut asumsi peneliti responden sebagian besar laki-laki karena umumnya pasien ditemani oleh suami ataupun anak laki-laki. Menurut penelitian Nasrani (2015) pada umumnya laki-laki dapat menikmati suatu masalah dan menganggap bahwa masalah dapat memberikan dorongan yang positif, sehingga laki-laki lebih bisa merawat anggota keluarganya yang menderita kanker serviks dengan baik.

Karakteristik reponden berdasarkan pekerjaan didapatkan mayoritas keluarga bekerja sebagai lain-lain (petani, buruh, tidak bekerja, ibu rumah tangga dan sebagainya) yaitu sebanyak 30 orang responden $(56,6 \%)$. Hasil penelitian Nuraenah (2012) menemukan secara umum pekerjaan berhubungan dengan pemberian dukungan keluarga dalam merawat anggota keluarga yang sakit.

Karakteristik responden berdasarkan hubungan dengan keluarga mayoritas keluarga yang merawat penderita kanker serviks memiliki hubungan keluarga sebagai anak yaitu sebanyak 31 orang responden $(58,5 \%)$. Menurut UUD nomor 1 tahun 1974 pasal 46 ayat 2 tentang perkawinan dalam Yasmin (2017) yang berbunyi “jika anak telah dewasa, ia wajib memelihara menurut kemampuannya, orang tua dan keluarga dalam garis lurus ke atas, bila mereka itu memerlukan bantuannya", sehingga dapat diartikan anak bertanggung jawab untuk memelihara dan merawat dengan sebaik-baiknya, contohnya seperti memelihara dan merawat kesehatan orang tua.

Hasil penelitian menunjukkan bahwa 27 orang responden $(50,9 \%)$ memiliki stres sedang dan 26 orang responden $(49,1 \%)$ memiliki stres ringan dalam merawat penderita kanker serviks di ruang rawat inap Tulip dan Seruni Obgyn RSUD Arifin Achmad. Hasil 
Sri Dewi Zalmi ${ }^{1}$, Yulia Irvani Dewi ${ }^{2}$, Jumaini ${ }^{3}$, Faktor-faktor yang Mempengaruhi Stress Keluarga dalam Merawat Penderita Kanker Serviks

tersebut menunjukkan bahwa keluarga yang merawat penderita kanker serviks mengalami stres. Hal ini didukung dengan penelitian Nasution (2010) yang menunjukkan bahwa anggota keluarga merasakan stres pada saat merawat anggota keluarga yang sakit.

Hasil penelitian menunjukkan bahwa 51 orang responden $(96,2 \%)$ memiliki pengetahuan yang baik dalam merawat penderita kanker serviks. Berarti mereka mengetahui bagaimana cara merawat penderita kanker serviks. Pengetahuan dapat dipengaruhi oleh beberapa faktor seperti umur, pendidikan, dan pekerjaan (Health, 2009 dalam Linawati, 2013). Umur mempengaruhi pengetahuan seseorang dimana semakin bertambah umur maka akan semakin berkurang daya penangkapan informasi, sehingga pengetahuannya pun menurun (Sudiharti \& Solikhah, 2012).

Hasil penelitian menunjukkan bahwa 27 orang responden $(50,9 \%)$ memiliki persepsi yang positif dan 26 orang responden $(49,1 \%)$ memiliki persepsi yang negatif terhadap penyakit kanker serviks. Persepsi seseorang terhadap penyakit dapat dipengauhi oleh beberapa hal seperti stigma terhadap penyakit, persepsi terhadap kesembuhan penyakit dan persepsi terhadap kegawatan penyakit (Soedarjatmi., Istiarti., \& Widagdo, 2009).

Hasil penelitian menunjukkan bahwa 28 orang responden $(52,8 \%)$ merasa terbebani dalam membiayai perawatan penderita kanker serviks. Biaya perawatan kanker serviks membutuhkan dana yang tidak sedikit seperti biaya perawatan hingga biaya kebutuhan sehari-hari keluarga selama merawat anggota keluarga dengan kanker serviks. Menurut asumsi peneliti umur terendah pada penelitian ini adalah 19 tahun dan tertinggi adalah 70 tahun. Responden dengan umur 19 tahun merasa tidak terbebani dengan biaya perawatan kanker serviks, namun sebaliknya bagi responden yang berumur 70 tahun merasa terbebani dengan biaya perawatan kanker serviks. Hal ini dapat disebabkan karena responden yang berumur 19 tahun bukanlah sebagai kepala keluarga yang harus membiayai semua keperluan keluarga, sedangkan responden yang berumur 70 tahun merupakan seorang suami, ayah dan juga kepala keluarga yang harus membiayai semua keperluan 
keluarga. Menurut Ali (2010) didalam keluarga, ayah berperan sebagai pencari nafkah, pelindung, pemberi rasa aman anggota keluarga, sedangkan anak berperan sebagai pelaku psikososial yang sesuai dengan perkembangan fisik, mental, sosial dan spiritual. Jadi dapat disimpulkan bahwa ayah atau suami memiliki peran dan tanggung jawab yang lebih besar dibandingkan dengan anak, sehingga ayah lebih mudah terbebani dan mengalami stres dibandingkan dengan anak.

Hasil penelitian menunjukkan bahwa 28 orang responden $(52,8)$ merasa terbebani selama menemani penderita dalam menjalani proses perawatan kanker serviks. Menurut penelitian Kharisma (2014) proses perawatan kanker serviks itu lama, mulai dari mengikuti jadwal rutin kemoterapi, operasi dan menemani pasien kontrol hingga bolak-balik rumah sakit yang harus dijalani oleh keluarga dan pasien. Dimana proses ini menghabiskan waktu yang banyak, yang menyebabkan keluarga yang merawat harus merubah gaya hidupnya dengan lebih memberikan waktu yang banyak kepada penderita kanker serviks. Dari hasil penelitian mayoritas keluarga yang menemani penderita kanker serviks berada pada rentang umur dewasa awal. Menurut asumsi peneliti masa dewasa awal merupakan masa dimana seseorang membutuhkan waktu yang banyak dengan lingkungnnya, karena pada masa inilah mulai mencari karir dan pasangan hidup. Hal ini didukung dengan penelitian Henrietta (2012) yang menyatakan bahwa pada masa dewasa awal terjadi pembentukan kemandirian seseorang secara pribadi maupun ekonomi, seperti perkembangan karir, pemeliharaan pasangan dan memulai keluarga. Dalam merawat keluarga yang sakit kita harus meluangkan waktu yang lebih banyak demi mendukung kesembuhan keluarga, sedangkan pada masa dewasa awal butuh waktu yang banyak untuk mengembangkan karir, memulai keluarga ataupun mencari pasangan hidup. Oleh sebab itu, kondisi ini akan menyebabkan keluarga menjadi tidak nyaman dan terbebani karena harus merawat keluarganya, sedangkan pada masa dewasa awal ini harus mengembangkan karir, memulai keluarga ataupun mencari pasangan hidup. 
Sri Dewi Zalmi ${ }^{1}$, Yulia Irvani Dewi ${ }^{2}$, Jumaini ${ }^{3}$, Faktor-faktor yang Mempengaruhi Stress Keluarga dalam Merawat Penderita Kanker Serviks

\section{Analisis Bivariat}

a. Hubungan pengetahuan keluarga dalam merawat penderita kanker serviks dengan tingkat stres dalam merawat penderita kanker serviks

Hasil penelitian ditemukan bahwa tidak terdapat hubungan antara pengetahuan keluarga dalam merawat penderita kanker serviks dengan tingkat stres keluarga dalam merawat penderita kanker serviks $p$ value $=$ 0,491. Hasil penelitian ini tidak sesuai dengan dengan penelitian Perwitasari (2015) yang menyatakan bahwa semakin tinggi pengetahuan seseorang maka akan lebih mampu seseorang untuk mengatasi stres yang terjadi didalam dirinya. Mayoritas keluarga yang merawat penderita kanker serviks memiliki pengetahuan yang baik dalam merawat penderita kanker serviks yaitu sebanyak 51 orang responden $(96,2 \%)$, akan tetapi mereka tetap merasakan stres dalam merawat anggota dengan kanker serviks. Menurut asumsi peneliti stres yang dirasakan keluarga dalam merawat penderita kanker serviks, bukan berasal dari pengetahuan yang dimiliki akan tetapi dari faktor lain. Hal ini sesuai dengan penelitian yang telah dilakukan peneliti dimana faktor yang dapat mempengaruhi terjadinya stres dalam merawat penderita kanker serviks adalah persepsi terhadap penyakit, biaya perawatan serta proses perawatan kanker serviks.

\section{b. Hubungan persepsi keluarga terhadap penyakit dengan tingkat stres dalam merawat penderita kanker serviks}

Hasil penelitian ditemukan bahwa terdapat hubungan antara persepi keluarga terhadap penyakit kanker serviks dengan tingkat stres keluarga dalam merawat penderita kanker serviks $p$ value $=0,000$. Hasil penelitian ini didukung oleh penelitian Sinamao (2010) yang menyatakan bahwa persepsi seseorang dapat mempengaruhi terjadinya stres.

Menurut Nasri dan Muhith (2011) persepsi seseorang terhadap sesuatu dapat mempengaruhi kadar stres seseorang, dimana hal ini sangat bergantung kepada bagaimana seseorang tersebut mengontrol stres seperti selalu berfikir positif, mempersiapkan diri terhadap stres yang akan datang dan menganggap stresor yang datang itu adalah 
suatu hal yang mengasyikkan, sehingga kadar stres menjadi lebih ringan.

\section{c. Hubungan biaya perawatan kanker serviks dengan tingkat stres dalam merawat penderita kanker serviks}

Hasil penelitian ditemukan bahwa terdapat hubungan antara biaya perawatan dengan tingkat stres keluarga dalam merawat penderita kanker serviks $p$ value $=0,003$. Farhan (2014) menyatakan bahwa tanggungan semua biaya perawatan ataupun biaya hidup sehari-hari keluarga saat merawat pasien dapat menyebabkan stres pada keluarga. Pada saat ada anggota keluarga yang sakit maka biaya kehidupan juga akan meningkat, seperti biaya kebutuhan sehari-hari: makan dan transportasi bolak-balik ke rumah sakit. Biaya ini belum termasuk biaya perawatan pasien yang tidak di tanggung oleh asuransi kesehatan. Kondisi ini dapat menjadi stresor pada keluarga dalam merawat anggota keluarga dengan kanker serviks.

\section{d. Hubungan proses perawatan kanker serviks dengan tingkat stres keluarga dalam merawat penderita kanker serviks}

Hasil penelitian ditemukan bahwa terdapat hubungan antara proses perawatan dengan tingkat stres keluarga dalam merawat penderita kanker serviks (0,004). Penyakit kanker serviks termasuk ke dalam golongan penyakit kronis yang penyembuhannya membutuhkan waktu lama. Menurut penelitian Denham dan Looman (2010) keluarga yang hidup dengan penderita sakit kronis menghadapi tantangan berat dalam hidup mereka berupa stres, kecemasan dan kemarahan akibat rutinitas pengobatan yang harus mereka lakukan.

\section{SIMPULAN}

Berdasarkan hasil penelitian dapat disimpulkan bahwa tidak terdapat hubungan antara pengetahuan keluarga dalam merawat penderita kanker serviks dengan tingkat stres keluarga dalam merawat penderita kanker serviks. Hasil penelitian yang berhubungan secara bermakna adalah antara persepsi keluarga dalam merawat penderita kanker serviks, biaya perawatan dan proses perawatan dengan tingkat stres keluarga dalam merawat penderita kanker serviks. 
Sri Dewi Zalmi ${ }^{1}$, Yulia Irvani Dewi ${ }^{2}$, Jumaini ${ }^{3}$, Faktor-faktor yang Mempengaruhi Stress Keluarga dalam Merawat Penderita Kanker Serviks

\section{SARAN}

Hasil penelitian ini dapat menjadi sumber data awal dalam peningkatan dan pengembangan penelitian lanjutan tentang faktor-faktor yang mempengaruhi stres keluarga dalam merawat anggota keluarga dengan kanker serviks. Disarankan untuk peneliti selanjutnya untuk menganalisis faktor yang paling berpengaruh terhadap stres keluarga dalam merawat penderita kanker serviks

\section{DAFTAR PUSTAKA}

Ali, Z. (2010). Pengantar keperawatan keluarga. Jakarta: EGC

Denham, S.A., \& Looman, W. (2010). Families with chronic illness, dalam Kaakinen, et al, Family health care nursing, theory, practice and research (4th Ed.). F.A Davis Company: Philadelphia. Hal 235- 272

Farhan, Z., Ibrahim, K., \& Sriati, A. (2014). Prediktor stres keluarga akibat anggota keluarganya dirawat di General Intensive Care Unit. Majalah Kedokteran Bandung, 46 (3), 150-154.

Husna, S, A. (2018). Faktor- faktor yang mempengaruhi stres keluarga dengan anggota keluarga dirawat di ruang Intensive Rumah Sakit Umum Daerah Dr. Zainoel Abidin Banda Aceh. Diperoleh pada tanggal 2 Juni 2019 dari https://etd.unsyiah.ac.id/index.php? $p=s h$ ow_detail\&id $=42675$

Henrietta, P. (2012). Impulsive buying pada dewasa awal di Yogyakarta. Jurnal Psikologi, 11(2), 6.

IARC. (2018). Latest global cancer data: Cancer burden rises to 18.1 million new cases and 9.6 million cancer deaths in 2018. International Agency for Research On Cancer. Geneva. Diperoleh pada tanggal 2 Juni 2019 dari https://www.iarc.fr/wp-content/uploads/ 2018/09/pr263_E.pdf

Kharisma, F. (2014). Respon dan koping keluarga terhadap penderita kanker serviks yang mendapat kemoterapi di RSUD Dr. Moewardi Surakarta. Diperoleh pada tanggal 2 Juni 2019 dari http://eprints.ums.ac.id/30951/12/NASK AH_PUBLIKASI.pdf

Linawati, L. (2013) Tingkat pengetahuan wanita usia subur tentang kista ovarium di Desa Jabung Sragen Tahun 2013. Laporan penelitian Stikes Kusuma Husada.

Nasrani, L. (2015). Perbedaan tingkat stres antara laki-laki dan perempuan pada peserta yoga di kota Denpasar. E-Jurnal Medika Udayana, 4 (12).

Nuraenah, N., Mustikasari, M., \& Putri, Y. S. E. (2014). Hubungan dukungan keluarga dan beban keluarga dalam merawat anggota dengan riwayat perilaku kekerasan di RS. Jiwa Islam Klender Jakarta Timur 2012. Jurnal Keperawatan Jiwa, 2 (1), 41-50.

Perwitasari, D. T. (2016). Faktor-faktor yang mempengaruhi tingkatan stres pada tenaga kesehatan di RS Universitas 
Jurnal Ners Indonesia, Vol.10 No.2, Maret 2020

Tanjungpura Pontianak Tahun

2015. Jurnal Mahasiswa PSPD FK

Universitas Tanjungpura, 2 (3).

Pusdatin. (2015). Stop kanker. Jakarta:

Kemenkes RI

Retno. (2019). Masa dewasa awal definisi perkembangan ciri menurut para ahli. Diperoleh pada tanggal 1 Juni 2019 dari https://dosenpsikologi.com/perkembanga n-kognitif-pada-dewasa-awal.

Sinamo, B. E. (2010). Pengaruh persepsi mengenai birokrasi terhadap stres kerja pada perawat Rumah Sakit Pringadi Medan. Diperoleh tanggal 2 Juni 2019 dari http://repository.usu.ac.id/handle/ 123456789/14530

Soedarjatmi, S., Istiarti, T., \& Widagdo, L. (2009). Faktor-faktor yang melatarbelakangi persepsi penderita terhadap stigma penyakit kusta. The Indonesian Journal of Health Promotion (Jurnal Promosi Kesehatan Indonesia), 4 (1), 18-24.

Sudiharti, S., \& Solikhah, S. (2012). Hubungan pengetahuan dan sikap dengan perilaku perawat dalam pembuangan sampah medis di rumah sakit PKU Muhammadiyah yogyakarta. Kes Mas: Jurnal Fakultas Kesehatan Masyarakat Universitas

Suerni, T. (2012). Analisis faktor-faktor yang Berhubungan dengan tingkat stress perawat ICU di RSU di Jawa Tengah. Diperoleh pada tanggal 1 Juni 2019 dari https://scholar.google.com/scholar?hl=i $d \& a s \_s d t=0,5 \&$ cluster $=1508422326487$ 8956619

Supriyanto, W. (2015). Kanker: Pengobatan dan Penyembuhannya. Yogyakarta: Parama Ilmu.

Sukmarini, N. (2009). Optimalisasi peran caregiver dalam penatalaksanaan skizofrenia. Bandung: Majalah Psikiatri XLII (I).

Yasmine, C., Ismi, H., \& Hasanah, U. (2018). Pelaksanaan kewajiban anak terhadap Orang Tua: Studi kasus unit pelaksana teknis Pelayanan Sosial Tresna Werdha (PSTW) Khusnul Khotimah Pekanbaru Ditinjau Dari Undang-Undang Nomor 1 Tahun 1974 Tentang Perkawinan 